\title{
INCREASING THE KNOWLEDGE AND CONFIDENCE OF MOTHERS IN CARING FOR LOW BIRTH WEIGHT BABIES THROUGH EDUCATION FROM THE MATERNAL AND CHILD HEALTH HANDBOOK
}

\author{
Sugiarti $^{1}$, Yeni Rustina*2, Defi Efendi ${ }^{2,3}$
}

1. Post Graduate Nursing Program, Faculty of Nursing, Universitas Indonesia, Depok, Indonesia

2. Department of Pediatric Nursing, Faculty of Nursing, Universitas Indonesia, Depok, Indonesia

3. Neonatal Intensive Care Unit, Universitas Indonesia Hospital, Depok, Indonesia

\begin{abstract}
Having a Low Birth Weight (LBW) is one of the risk factors that may lead to stunting in children under five years old. An education program based on the Maternal and Child Health handbook (MCH) for the first 1000 days of a child's life is one way to prevent the impact of stunting by improving the mothers' knowledge and self-confidence to look after LBWB. The study is designed along the line of pre-post quasi-experimental research with a control group, involving 69 samples of mothers with LBWB that match the predetermined criteria. Twenty three of these mothers whose babies were cared for in the perinatology ward were provided with instructions from the $\mathrm{MCH}$ handbook, another group of 23 mothers received the same instructions with additional audiovisual media from a mobile application, and the remaining 23 mothers only received verbal instructions in the ward. The data were analyzed using the Paired t-test/Wilcoxon and Kruskall-Wallis tests. The analysis revealed that the $\mathrm{MCH}$ handbook based instruction provided a significant boost on the score of mother's knowledge and confidence, before and after they have received the instructions, both in the group that received the $\mathrm{MCH}$ handbook based instruction $(p<0.001)$ and the group that received their instructions from a mobile application $(p<0.001)$. Additional instructions using audiovisual media from a mobile application also provided a significant boost to the knowledge score, and therefore the post-education score of the mothers in this group was higher than in the other two groups $(p<0.001)$. Mother's knowledge of the provision of care for LBWB can therefore be optimized through education, discussion, and the use of technology as an instructional medium to complement the use of the $\mathrm{MCH}$ handbook.
\end{abstract}

Keywords: low birth weight, $\mathrm{MCH}$ handbook, education, confidence, knowledge

ABSTRAK
Bayi Berat Lahir Rendah (BBLR) menjadi salah satu faktor risiko utama terjadinya stunting pada balita.
Edukasi berbasis Kesehatan Ibu dan Anak (KIA) pada periode 1000 hari pertama kehidupan anak
merupakan salah satu cara untuk mencegah dampak stunting melalui upaya peningkatan pengetahuan
dan kepercayaan diri ibu dalam merawat BBLR. Desain penelitian quasi exsperiment pre-post with
control group dengan melibatkan 69 sampel ibu yang memiliki BBLR sesuai kriteria. Sejumlah 23 ibu
yang memiliki bayi di rawat di ruang perinatologi, diberikan edukasi dengan media pembelajaran buku
KIA, dan 23 ibu diberikan edukasi ditambah media audiovisual mobile application, dibandingkan dengan
23 ibu yang hanya mendapatkan informasi rutin ruangan. Analisis data menggunakan uji paired t-
test/Wilxocon dan Kruskall-Wallis. Hasil analisis mengidentifikasi edukasi berbasis buku KIA
memberikan pengaruh yang signifikan terhadap peningkatan skor pengetahuan dan kepercayaan diri
ibu yaitu antara sebelum dan setelah edukasi, baik pada kelompok edukasi buku KIA ( $p<0.001)$
maupun pada kelompok edukasi mobile application ( $p<0.001$ ). Edukasi dengan tambahan media
audiovisual mobile application juga secara signifikan memberikan pengaruh terhadap skor pengetahuan
post-edukasi yang lebih baik dari kedua kelompok lainnya ( $p<0,001$ ). Pengetahuan ibu terkait
perawatan yang optimal pada BBLR dapat ditingkatkan melalui praktik edukasi, diskusi, dan
penggunaan teknologi sebagai media pembelajaran guna menunjang aksesibilitas buku KIA.
Kata kunci: bayi berat lahir rendah, buku KIA, edukasi, kepercayaan diri, pengetahuan




\section{BACKGROUND}

The prevalence of children under five years old with stunted growth in Indonesia is quite significant at $30.8 \%$ (Kementerian Kesehatan RI Badan Penelitian dan Pengembangan, 2018). Stunting in children under five years old is a serious national issue in Indonesia, and even worse, the national figure has exceeded the threshold set forth by the World Health Organization (WHO). Low Birth Weight (LBW) is one of the risk factors that may lead to the occurrence of stunting throughout the world followed closely by poor sanitation and diarrhea (Danaei et al., 2016).

A malnourished fetus will usually be born with a LBW condition and it may lead to stunted growth/stunting and eventually affect their cognitive development (Chalid, 2014; Prendergast \& Humphrey, 2014). This condition has short and long-term consequences and it also affects a child's morbidity and mortality rate (Stewart et al., 2013; Sjarif et al., 2015). Stunting in a child under two years old is still responsive to treatment and can be preventable through intervention (Prendergast \& Humphrey, 2014). Focused care for children with LBW as the high risk population during the first 1000 days of life must be maximized, one way is to optimize child health care using the $\mathrm{MCH}$ handbook as a guideline in providing care from the earliest age and promoting it continuously. A study by Mori et al. (2015) recommends the use of information technology, such as a smartphone, to facilitate the implementation of health interventions and increase $\mathrm{MCH}$ handbook accessibility. A cellular application installed in a smartphone may improve the perinatal care by facilitating access to information on health related matters, modifying service requests, and providing the required services (Agarwal \& Labrique, 2014). It also allows a patient to receive information on health related matters, and to interact and get involved in the care (Ledford, Canzona, Cafferty, \& Hodge, 2016).

Low birth weight requires special care both in the hospital and at home, which includes, among other things, providing stimulation to the infants' growth and development. A mother's knowledge and perception with regard to her own knowledge will influence her behavior in caring for the infant. The issue here is that, a mother with LBWB tends to have low self-confidence in providing the necessary care for her child, which may stem from a lack of knowledge, insufficient experience, and an overall lack of skills in caring for the child (Kenanga Purbasary, Rustina, \& Budiarti, 2017; Premji et al., 2018). A drop in self-confidence among mothers may also occur in the first two months after birth and when they are at home alone with their babies (Premji et al., 2018). Preparing a mother to be ready to care for her baby at home must be done gradually, even though the implementation is still hindered by the fact that the mother may not have received full instructions on the care of an infant with Low Birth Weight when it is time for the baby to be discharged from the hospital, resulting in a number of topics then being crammed into a single session (Rustina, Wanda, Waluyanti, \& Kusumasari, 2016). This may lead to the baby being readmitted to the hospital to be treated for something that is preventable.

The integration of the $\mathrm{MCH}$ handbook into other programs is still somewhat inadequate. The preliminary findings in a number of hospitals in the Province of Lampung revealed that not all health facilities provide expectant mothers with the $\mathrm{MCH}$ handbook. Also a number of mothers said they rarely read the $\mathrm{MCH}$ handbook, and some even said that they never read it at all. Important information on the care of newborn babies in the $\mathrm{MCH}$ handbook is not included in the standards for discharging babies from the hospitals. The objective of the study is find out and compare the effect of $\mathrm{MCH}$ based education on the knowledge and level of self-confidence among mothers in providing care for LBW between the group that received their information from the $\mathrm{MCH}$ handbook as the instructional media and the group that also received complementary audiovisual information from the mobile application in addition to the $\mathrm{MCH}$ handbook, and last but not least the control group that only received verbal instruction in the hospital wards. 


\section{METHOD}

The study employed a pre and post quasi-experimental research design with a control group. The samples in the study were collected using a consecutive sampling method, wherein the samples were collected using sequentialsampling/per group. First, the samples were collected for the control group, followed by samples for the intervention $A$ and intervention $B$ groups. Sixty-nine mothers with LBWB were included in the study, of those 23 of them were grouped as the control group, 23 mothers as the intervention group $A$, and the remaining 23 mothers as the intervention group $B$. The study was conducted for 2 months in three perinatology wards in hospitals located in the Province of Lampung in 2019. The predetermined inclusion criteria were as follows: mothers with LBWB, the LBWB in question were not using breathing apparatus support; the mothers were able to read and write, they had their own Android based smartphone, and were willing to participate in the research.

Intervention in this case is the education on "the care of LBW during the essential neonatal period after the birth of a child until the child reaches the age of two years", which was delivered using a flipchart (the material was taken from the $\mathrm{MCH}$ handbook and other relevant literatures on essential care for LBW) with additional instructional media in the form of the $\mathrm{MCH}$ handbook or audiovisual media delivered using the mobile application. The intervention group A was instructed using the material from the $\mathrm{MCH}$ handbook as the instructional media, the intervention group B was instructed using audiovisual media from the mobile application, and the control group only received verbal instructions during their stay in the hospital ward. The audiovisual media from the mobile application was developed by the research team consisting of experts in video animation as well as a computer programmer. The Android based application is appropriately called "Edukasi Perawatan BBLR di rumah", which can be downloaded free from the PlayStore. The app teaches its users to care for infants, and the material therein is taken from the $\mathrm{MCH}$ handbook with additional sections tailored specifically to providing essential care for low birth weight babies.

The pre-test was conducted prior to the education sessions. Education for the intervention group $A$ and $B$ was carried out in 2 sessions for approximately 2 hours per session. The intervention group $A$ was given additional instructional media in the form of the $\mathrm{MCH}$ handbook; meanwhile, the intervention group $B$ was given the audiovisual mobile application. The first session discussed topics on essential neonatal care after the birth of a child until they reach the age of two years, and in the next session, the discussion covered topics on nutritional needs and child growth and development. At the end of each session, the mothers were asked to fill in the group's logbook and encouraged to study on their own at home using the media specifically for their group. At the end of the study, the intervention group $A$ and the control group were given the posttest and additional instructions using the same audiovisual mobile application.

The instrument used for collecting the data was a questionnaire, which explores how much the respondents knew about providing care for LBWB and it was tested for its validity and reliability (Cronbach alpha 0.914), using the Maternal Confidence Questionnaire (MCQ), which has been translated into the Indonesian Language (Cronbach alpha 0.86-0.93) (Badr, 2005). The paired group data were analyzed using the Paired t-test and Wilcoxon test; and the Kruskal-Wallis test for the unpaired group. The study was endorsed by the Research Ethics Committee of the Faculty of Nursing, Universitas Indonesia (document No.25/UN2.F12.D/HKP.02.04/ 2019).

\section{RESULT}

Respondents' characteristics (Table 1) showed that the respondents' age in the three groups was early adulthood (26-35 years old) with an average proportion of $52.17 \%$. As for their educational level, the majority of mothers in the control group and in the group instructed using the $\mathrm{MCH}$ handbook had completed primary and secondary schools, whereas most of the mothers in 
the group instructed using audiovisual media from the mobile application had completed middle and higher education. Most of the mothers were also unemployed (with a total family income of $\leq \operatorname{Rp} 2,000,000$ ) and had no previous experience in caring for LBWB. They had full support from their families in caring for LBWB (LBW meaning the birth weight of these babies was between 1,500 to 2,500 grams.
Statistical analysis was carried out using the Paired t-test or Wilcoxon test to learn about the changes in the score of the knowledge and self-confidence of the mothers in providing the necessary care to LBWB before and after receiving the instructions (Table 2). The Kruskal-Wallis test was used to analyze the difference in the scores of knowledge and selfconfidence, and the difference in mothers' self-confidence in caring for LBWB among the respondents (as shown in Table 3).

Table 1. Frequency Distribution and Percentage of Respondents Characteristics $(n=69)$

\begin{tabular}{|c|c|c|c|c|c|c|}
\hline \multirow{2}{*}{ Variables } & \multicolumn{2}{|c|}{ Control } & \multicolumn{2}{|c|}{ MCH Handbook } & \multicolumn{2}{|c|}{ Mobile Application } \\
\hline & $\mathbf{n}$ & $\%$ & $\mathbf{n}$ & $\%$ & $\mathbf{n}$ & $\%$ \\
\hline \multicolumn{7}{|l|}{ Age } \\
\hline Teen $(12-25)$ & 4 & 17,4 & 10 & 43,5 & 6 & 26,1 \\
\hline Early adulthood (26-35) & 11 & 47,8 & 9 & 39,1 & 16 & 69,6 \\
\hline Late adulthood (36-45) & 8 & 34,8 & 4 & 17,4 & 1 & 4,3 \\
\hline \multicolumn{7}{|l|}{ Education level } \\
\hline Basic education & 9 & 39,1 & 10 & 43,5 & 2 & 8,7 \\
\hline Middle education & 8 & 34,8 & 8 & 34,8 & 14 & 60,9 \\
\hline Higher education & 6 & 26,1 & 5 & 21,7 & 7 & 30,4 \\
\hline \multicolumn{7}{|l|}{ Mother's occupation } \\
\hline Employed & 7 & 30,4 & 4 & 17,4 & 3 & 13 \\
\hline Unemployed & 16 & 69,6 & 19 & 82,6 & 20 & 87 \\
\hline \multicolumn{7}{|l|}{ Family income } \\
\hline$\leq$ Rp. $2,000,000$ & 14 & 60,9 & 14 & 60,9 & 11 & 47,8 \\
\hline$>$ Rp. $2,000,000$ & 9 & 39,1 & 9 & 39,1 & 12 & 52,2 \\
\hline \multicolumn{7}{|l|}{ Experience in caring for LBWB } \\
\hline Inexperienced & 20 & 87 & 22 & 95,7 & 22 & 95,7 \\
\hline Experienced & 3 & 13 & 1 & 4,3 & 1 & 4,3 \\
\hline \multicolumn{7}{|l|}{ Family support } \\
\hline Not supported & 0 & 0 & 1 & 4,3 & 4 & 17,4 \\
\hline Supported & 23 & 100 & 22 & 95,7 & 19 & 82,6 \\
\hline \multicolumn{7}{|l|}{ Birth weight } \\
\hline$<1000$ grams & 0 & 0 & 0 & 0 & 0 & 0 \\
\hline $1000-<1500$ grams & 8 & 34,8 & 6 & 26,1 & 3 & 13 \\
\hline $1500-<2500$ grams & 15 & 65,2 & 17 & 73,9 & 20 & 87 \\
\hline
\end{tabular}

Table 2. Changes in the scores of Knowledge and Self-Confidence among Mothers in Caring for LBWB before and after Receiving Instructions ( $n=69$ )

\begin{tabular}{|c|c|c|c|c|c|c|}
\hline Variable and Group & Period & $\begin{array}{l}\text { Mean } \\
\text { (SD) }\end{array}$ & $\begin{array}{c}\text { Median } \\
(\text { Min-Max) }\end{array}$ & Gap & $95 \% \mathrm{Cl}$ & p value \\
\hline \multirow{2}{*}{$\begin{array}{l}\text { Score of knowledge } \\
\text { Audiovisual education }{ }^{\text {b }}\end{array}$} & & & & & & \\
\hline & $\begin{array}{l}\text { Before } \\
\text { After }\end{array}$ & $\begin{array}{l}19,8(2,9) \\
29,4(1,6)\end{array}$ & - & 9,6 & $8,5-10,7$ & $<0,001^{*}$ \\
\hline \multirow{3}{*}{$\begin{array}{c}\mathrm{MCH} \text { handbook } \\
\text { education }^{\mathrm{b}} \\
\text { Control }^{\mathrm{a}}\end{array}$} & Before & $19,2(4,4)$ & - & 7,8 & $6,25-9,31$ & $<0,001^{*}$ \\
\hline & After & $27(2,6)$ & - & & & \\
\hline & $\begin{array}{l}\text { Before } \\
\text { After }\end{array}$ & - & $\begin{array}{c}17(9-27) \\
16(12-27)\end{array}$ & 1 & - & 0,243 \\
\hline \multirow{2}{*}{$\begin{array}{l}\text { Self-confidence score } \\
\text { Audiovisual education }{ }^{\text {b }}\end{array}$} & & & & & & \\
\hline & $\begin{array}{l}\text { Before } \\
\text { After }\end{array}$ & $\begin{array}{l}55,7(8,8) \\
59,9(6,8)\end{array}$ & - & $\begin{array}{c}4,21 \\
-\end{array}$ & $2,6-5,84$ & $<0,001$ \\
\hline \multirow{2}{*}{$\begin{array}{c}\mathrm{MCH} \text { handbook } \\
\text { education }^{\mathrm{b}} \\
\text { Control }^{\mathrm{a}}\end{array}$} & $\begin{array}{l}\text { Before } \\
\text { After }\end{array}$ & $\begin{array}{c}57,3(9,7) \\
63,53(5,7)\end{array}$ & - & $\begin{array}{c}6,23 \\
-\end{array}$ & $3,21-9,24$ & $<0,001$ \\
\hline & $\begin{array}{l}\text { Before } \\
\text { After }\end{array}$ & $\begin{array}{ll}- \\
-\end{array}$ & $\begin{array}{l}60(18-70) \\
59(18-70)\end{array}$ & $\begin{array}{l}1 \\
-\end{array}$ & - & 0,455 \\
\hline
\end{tabular}


aUji Wilcoxon, bUji Paired t-test

Remarks: *significant at $\alpha \leq 0.05$

Table 3. Differences in Knowledge and Self-Confidence, and the Difference in Confidence among Mothers in Caring for LBWB between Respondent Groups $(n=69)$

\begin{tabular}{lccc}
\hline Variable and Group & Median & (Min-Max) & p value \\
\hline Post-education knowledge score & 30 & $(26-32)$ & $<0,001^{*}$ \\
$\quad$ Audiovisual education & 27 & $(19-30)$ & \\
MCH handbook education & 16 & $(12-27)$ & \\
Control & & & \\
Post-education self-confidence score & 57 & $48-70$ & $<0,163$ \\
Audiovisual education & 64 & $49-70$ & \\
MCH handbook education & 59 & $18-70$ & \\
Control & & & \\
Difference in self-confidence Score & 4 & $0-11$ & $0,001^{*}$ \\
Audiovisual education & 4 & $0-28$ & \\
MCH handbook education & 1 & $0-6$ & \\
Control &
\end{tabular}

Kruskal-Wallis Test. Mann-Whitney post hoc test: (knowledge score; self-confidence score; difference in self-confidence score). Control vs. Education $+\mathrm{MCH}$ handbook ( $\mathrm{p}$ value $<0.001 ; 0.108 ; 0.001$ ), Control vs. Education + audiovisual mobile application ( $p$ value $<0.001 ; 0.826 ; 0.003)$, and Education + $\mathrm{MCH}$ handbook vs. Education + audiovisual mobile application ( $p$ value $0.001 ; 0.09 ; 0.635$ )

Remarks: *significant at $\alpha \leq 0.05$

\section{DISCUSSION}

Educational interventions using a flipchart with the additional material from the $\mathrm{MCH}$ handbook and audiovisual media from the mobile application were quite effective in improving the level of knowledge and self-confidence among mothers with LBWB; meanwhile, the group that only received verbal instructions during their stay in the ward did not show any increase in the level of knowledge or self-confidence. This study provides the evidence that the $\mathrm{MCH}$ handbook, as an educational tool, is quite effective in improving the level of knowledge among mothers in "the care of LBWB during the essential neonatal period after the birth of a child until they reach the age of two years". Based on the indicators of knowledge, practices, and behaviors, the use of the $\mathrm{MCH}$ handbook has provided a positive impact, i.e. it is an effective tool in promoting maternal and child health and acts as an alternative method for educating new mothers and enabling them to provide better healthcare for their babies (Bhuiyan, Begum, Ehsan, \& Shah, 2018).

One way we can break the cycle of stunting in children is by improving the health status and improving health care for mothers and their children from an early age. Stunted growth in children who are less than 2 years old is still responsive, meaning it is preventable through intervention (Prendergast \& Humphrey, 2014). The $\mathrm{MCH}$ handbook contains comprehensive information that can be used to promote better health care and improve the health status of mothers during pregnancy as well as providing guidelines for raising their children (Bhuiyan et al., 2018; Osaki et al., 2019) in a continuous manner (Osaki et al., 2015). The benefit increases for the parents of LBWB or prematurely born babies who are in need of a higher standard of care (Mousavi et al., 2016); therefore, it is crucial that the health care team provide psycho-social support and appropriate health counseling that matches the parents' needs (Kuo et al. 2012; Mousavi et al. 2016). Health education or counseling in the form of providing information on health related matters is given to the mothers of premature babies to improve the mothers' knowledge and skills in providing care for their babies (Brett et al., 2011), and boost the mothers' self-confidence (Benzies, Magill-Evans, Hayden, \& Ballantyne, 2013; Kenanga, Rustina, \& Budiati, 2017; Premji et al., 
2018), which will help mothers deal with the stress of caring for vulnerable babies at home.

Studies on the benefits of owning and using the $\mathrm{MCH}$ handbook have been done many times, some of which are the studies on the users of services for infants and children, which lead to changes in the level of knowledge and self-confidence and ultimately improve the mothers' capacity to provide care at home. A study on the use of the $\mathrm{MCH}$ handbook for neonatal care users covers topics, such as early breastfeeding initiation, immediate breastfeeding, exclusive breastfeeding, and introduction to complementary food from breast milk, vitamin A intake, and the rate of morbidity and mortality among neonatal infants (Yanagisawa et al., 2015; Mori et al., 2015; Osaki et al., 2015; Osaki et al., 2019). Meanwhile, the studies on children focus on immunization visits, visits by health care providers in the event of specific conditions (Upper Respiratory Tract Infection (URTI), fever, and diarrhea), providing proper nourishment, consuming a variety of food, training children to eat on their own, monitoring the occurrence of underweight children and stunted growth, and delays in the child's cognitive growth (Usman, Akhtar, Habib, \& Jehan, 2009; Usman et al., 2011; Dagvadorj, et al., 2017; Osaki et al., 2019). In addition to planning a comprehensive follow up care plan to hospital care and providing information pertaining to infant care, we may also need to develop community-based care such as home visits by medical staff or developing support groups (Kuo et al., 2012).

The current study also shows the effectiveness of the education program provided to mothers with LBWB, both for the group that used the $\mathrm{MCH}$ handbook and the group using the audiovisual media from the mobile application. Edgar Dale (1946) in his theory 'The Cone Experience' states that the use of instructional media in health education is based on the cone principle of experience that is related to the level of involvement, and the message/material remembered by the target (Davis \& Summers, 2015). Based on the level of its involvement, we learned that in any educational process, the target would remember the message/material if they are directly involved in the process, compared to if the message/material is simply delivered through verbal instructions or visual media. Referring to that theory, in the study the researchers initially presented the material through lectures, which were followed by discussions where the targets were directly involved and followed by instructions in the form of audiovisual media and the $\mathrm{MCH}$ handbook; therefore, we hoped that the participants' understanding of the material would reach $50 \%$. Moreover, UNESCO (2013) stated that even though cellular devices are relatively affordable and they do provide some benefits, they should not replace but rather complement the existing investment in education such as textbooks or training provided by human instructors. It means that instructional media such as mobile applications in cellular devices or books such as the $\mathrm{MCH}$ handbook can have a positive impact; however, the existence of these media does not negate the role of direct education by health care professionals including nurses. This is because education is closely associated with the independent role of nurses as educators, namely through a communication process and interaction with patients. By preparing and providing mothers with the capacity to provide the necessary care for LBWB and when supported by the appropriate instructional media, the mothers are expected to be able to provide optimal care to their LBWB after they have been discharged from the hospital. This view is in line with a study by (Prabhakaran, 2015) which argues that a structured learning program using pamphlets for 7 days is an effective strategy in increasing the mothers' knowledge with regard to providing care for LBWB in hospitals, wherein the average score of knowledge is higher after attending the program compared to the level before ( $p$ value $<0.001$ ). Other similar studies also reveal that health education packages are quite effective in improving the knowledge and practices of postnatal mothers in the care of LBWB (Bhoknal, 2018). 
Other studies have also pointed out that educational programs on baby care have a positive impact on increasing the mothers' self-confidence. It is as stated by Cinar and Ozturk (2014) in their quasiexperimental study (pre-post test) whose objective is to examine the effect of educational instructions about infant care on the level of self-confidence among primiparous mothers. In that study, the mothers in the intervention group were given a structured instruction on infant care accompanied with an instructional booklet; meanwhile, the mothers in the control group were not given anything. The study concluded that there is a significant increase in the mothers' self-confidence scores in the intervention group ( $p$ value $<0.001$ ), whereas in the control group there is no difference ( $p$ value 0.97 ). The effectiveness of educational instructions in increasing the mothers' self-confidence is also shown by the research by Kucukoglu and Celebioglu (2014) carried out in Turkey that evaluated the impact of providing health education using a special booklet on exclusive breastfeeding on LBWB, and it has been proven effective in increasing the mothers' self-confidence in breastfeeding LBWB. These results are also consistent with a study by (Bagherinia, Mirghafourvand, \& Shafaie, 2017) conducted on 135 mothers in the postpartum period, which concluded that the educational package has a positive impact in increasing the mothers' selfconfidence and their functional status.

The use of smartphone technology in the form of a mobile application is considered as an efficient way to provide health information in various clinical settings of health services (Dalton et al., 2018). Increasing mothers' knowledge with regard to the use of mobile applications in the current study is in line with a study by (AlKlayb et al., 2017) about the use of a mobile-based application that can significantly improve the mothers' knowledge of their children's oral health, by comparing the data of the questionnaires filled in after using the mobile application and the mothers' previous knowledge on the subject before they downloaded the application. The app was developed for iPhone and Android phones and can be downloaded for free from the AppStore or PlayStore. The study is also analogous to the nonequivalent control group pre-post test design conducted by Lee and Kim (2017) whose objective is to develop a mobile cellular application and test its effect on the knowledge and self-confidence in primiparous mothers. In the study, statistically speaking, the mothers' knowledge and level of self-confidence with regard to infant and postpartum care increased as a result of using the mobile application. With the rapid growth of internet technology today, perinatal educators and professional nurses working in the perinatal health area need to guide and facilitate the mothers to seek out and learn from online resources to reduce false, excessive, and unnecessary information (Buultjens, Robinson, \& Milgrom, 2012). The study also shows an increase in the use of the internet to seek out health related information and facilities. The mobile application developed for this study provides easy access and a convenient way for the mothers to learn; therefore, it is expected that the use of the mobile application will increase the readiness and selfconfidence of mothers to provide care to LBWB at home. These findings are also supported by an ethnographic study conducted by Gibson and Hanson (2013) on the role of technology in supporting new mothers (early period after the birth of a baby) since there is a clear need to boost the mothers' self-confidence and for them to be more than just mothers.

The majority of mothers with LBWB in this study said that they received the $\mathrm{MCH}$ handbook during an antenatal examination conducted by the local midwives or at the Community Health Center (Puskesmas); however, there were no significant changes with regard to the mothers' knowledge and self-confidence between the pre-post control groups. The researchers, therefore, argue that there are limited opportunities for the mothers to seek and obtain information, because while in the hospital they are preoccupied with their daily routines such as expressing breast milk for their babies and visiting the babies during the visiting 
hours.

This opinion is reinforced by the findings of the research by (Auger, Reich, \& Penner, 2014) on the provision of free educational books on infant care to expectant mothers up to one year after giving birth, which points out that the provision of these free educational books would only provide a significant impact if the mothers were willing to read the book; however, it had no effect on the mothers' reading habits. The study also shows that up to 12 months after giving birth, there was an increase in reading frequency among new mothers.

The analysis also showed that educational intervention with complementary audiovisual instructional media can significantly boost the knowledge score of the mothers to a higher level than the other two groups. The difference in the level of knowledge after participating in the $\mathrm{MCH}$ handbook instructional education is also related to the active participation of the mothers of LBWB as the research respondents. The mothers in the study were actually quite cooperative; they followed the researchers' directions well and played an active role in the learning program. The findings are also comparable with the randomized control trial study by (Ledford et al., 2016), which compared the use of a cellular application educational tool for expectant mothers against a conventional paper-based educational tool. The study reveals that there was an increase in active involvement and learning among mothers who used the mobile application compared to the users of a conventional paper-based educational tool. Susilowati (2016) claimed that the use of audiovisual media from a mobile application in health education will provide an effective level of understanding of the material up to six times better for the participants and 3.5 times better when the instruction is delivered using visual media compared to plain verbal instructions. This is in line with the findings of the current study, which shows that both instructional media, the $\mathrm{MCH}$ handbook and the mobile application, have a positive impact on improving the knowledge of mothers with LBWB; nonetheless, audiovisual media from a mobile application is more effective compared to the $\mathrm{MCH}$ handbook (visual). Audiovisual media from a mobile application involves more sensory stimulation and makes it easier for the mothers to grasp the material, i.e. they only need to watch and listen to the presentation, compared to the mothers who have to read the material.

The result of the study also indicates the rather inconsequential effect of the $\mathrm{MCH}$ handbook based instructions on the self-confidence of mothers with LBWB between the three groups of respondents; nevertheless, the analysis of the difference in the mothers' selfconfidence reveals that the interventions did have the effect of boosting the mothers self-confidence, even though the increase was relatively insignificant when compared to the group that only received verbal instructions. With regard to these findings, the researchers are of the opinion that the intervention will have more impact in improving the self-confidence score if it is given over a longer period. That opinion is supported by the study by Lee and Kim (2017) that points to significant changes in the mothers' self-confidence after attending 6 weeks of instructional education using the mobile application. However, it differs slightly from the study by (Ledford et al., 2018) whose objective was to test the effectiveness of a cellular mobile application as a substitute for prenatal education logbooks. The study concluded that the cellular mobile application has a strong empowering effect on its users in addition to attracting their interest in using the app; however, one aspect that would determine the adoption and success of the app is how the healthcare system encourages its use. The design and development of a cellular mobile application, especially those related to medical or psychological fields, needs to be carried out well so it can attract the users' attention to using it continuously (Sharma, Dirin, \& Hosseini, 2017).

To find out how significant the increase in the mothers' self-confidence was, as a result of the intervention in the current study, it is necessary to establish some sort of uniformity on the postpartum 
age which can be measured; as well as reestablishing the time to measure the mothers' self-confidence score as adjusted to the Mercer's theory (the period between 2 weeks and 4 months of postpartum). Mercer in Alligood (2017) argues that the stage of achieving the maternal role is close to normalization, i.e. within the period of the second week to the fourth month after giving birth. This opinion is in accordance with the study by Fasanghari, Kordi, and Asgharipour (2019), which examined the mothers' role through a training program in accordance with the Mercer theory. They determined that there was a significant change in the mothers' self-confidence between the pre-training and the 4 week period after giving birth $(p=0.001)$, and between 4 months after giving birth, 4 weeks after giving birth and before participating in the training $(p=0.001)$.

The educational interventions and the instructional media provided in the study are not the only factors affecting the level of self-confidence among mothers with LBWB. A study by Dalton et al. (2018) shows that the self-confidence level among expectant mothers who used the Health E-babies application and those who did not use the app did not differ significantly ( $p$ value 0.73 ). The study also provided an important insight with regard to challenges in implementing mobile application technology in communities that are socially disadvantaged, i.e. communities that have to deal with social and mental health issues, financial-related constraints, and have only a basic ability to utilize technology. A study by Bandura asserted that mothers' confidence is affected by their experience, replication, social persuasion, and psychological factors (Ribeiro \& Kase, 2017). Ha and Kim (2013) believe that $97.4 \%$ of a mother's self-confidence in her role during the postpartum period is affected by the parity and closeness of the mother to her baby. Parity association in this regard is confirmed by a study by Kristensen et al. (2018), which identified a decrease in a mother's self-confidence score during the two month postpartum period $(p$ value $<0.001$ ) in a large number of mothers who were having their first babies. In the current study, the researchers did not take into account the parity variable, either in the inclusion criteria or in the statistical analysis. The process of caring for infants in the hospital also contributes to the feeling among mothers that they are unable to carry out their full role as a mother, and it also hinders the bonding process between mothers and babies.

\section{CONCLUSION AND RECOMMENDA TION}

The $\mathrm{MCH}$ handbook based education program, with both the complementary $\mathrm{MCH}$ handbook instructional media and the Android-based audiovisual mobile application, significantly influences the knowledge and self-confidence of mothers with LBWB. A higher knowledge score is found among the mothers who received their instructions from audiovisual media using the mobile application. In a way it shows that an Android based mobile application can be an effective tool to provide instructional education in support of the $\mathrm{MCH}$ handbook while allowing mothers to provide the best care for LBWB at home. The use of instructional media in this study is complementary to providing health education, and it does not negate or reduce the role of professional nurses as educators and service providers. This educational activity should also be included in hospital's discharge planning standards. Further studies are recommended, which would suggest allowing house visits to make direct observations of the care provided by the mothers to get more comprehensive results.

\section{REFERENCES}

Agarwal, S., \& Labrique, A. (2014). Newborn health on the line: The potential m-health applications. Journal of the American Medical Association, 312(3), 229-230. https://doi.org/10.1001/jama.2014.63 71

AlKlayb, S. A., Assery, M. K., Al-Qahtani, A., Al-Anazi, M., \& Pani, S. C. (2017). Comparison of the effectiveness of a mobile phone- 
based education program in educating mothers as oral health providers in two regions of Saudi Arabia. Journal of International Society of Preventive and Community Dentistry, 7(3), 110-115. https://doi.org/10.4103/jispcd.JISPC D

Alligood, M. R. (2017). Nursing theorists and their work, ( $8^{\text {th }}$ ed.). St. Louis: Mosby Elsevier Health Sciences.

Auger, A., Reich, S. M., \& Penner, E. K. (2014). The effect of baby books on mothers' reading beliefs and reading practices. Journal of Applied Developmental Psychology, 35(4), 337-346. https://doi.org/10.1016/j.ap pdev.2014.05.007

Badr, L. K. (2005). Further psychometric testing and use of the Maternal Confidence Questionnaire. Issues in Comprehensive Pediatric Nursing, 28(3), 163-174. https://doi.org/10.10 80/01460860500227572

Bagherinia, M., Mirghafourvand, M., \& Shafaie, F. S. (2017). The effect of educational package on functional status and maternal self-confidence of primiparous women in postpartum period: A randomized controlled clinical trial. Journal of MaternalFetal and Neonatal Medicine, 30(20), 2469-2475. https://doi.org/1 0.1080/14767058.2016.1253061

Benzies, K. M., Magill-Evans, J. E., Hayden, K. A., \& Ballantyne, M. (2013). Key components of early intervention programs for preterm infants and their parents: A systematic review and metaanalysis. BMC Pregnancy and Childbirth, 13(S1), S10. https://doi. org/10.1186/1471-2393-13-s1-s10

Bhoknal, K. (2018). Effectiveness of health education package on knowledge and practice regarding care of low birth weight babies (LBW) among post natal mothers, 8(March), 167172. Retrieved from http://www.ijhsr.
org/IJHSR_Vol.8_Issue.3_March201 8/21.pdf

Bhuiyan, S., Begum, H., Ehsan, S., \& Shah, J. (2018). Maternal and Child Health $(\mathrm{MCH})$ handbook and its effect on maternal and child health care: A systematic review and metaanalysis. Journal of Community Medicine and Public Health, 02, 113. https://doi.org/10.29011/CMPH109/100009

Brett, J., Staniszewska, S., Newburn, M., Jones, N., \& Taylor, L. (2011). A systematic mapping review of effective interventions for communicating with, supporting and providing information to parents of preterm infants. BMJ Open, 1(1), e000023. https://doi.org/10.1136/bmj open-2010-000023

Buultjens, M., Robinson, P., \& Milgrom, J. (2012). Online resources for new mothers: opportunities and challenges for perinatal health professionals. The Journal of Perinatal Education, 21(2), 99-111. https://doi.org/10.1891/10581243.21.2.99

Chalid, M. (2014). Gambaran Umum Program 1000 Hari Awal Kehidupan. ResearchGate (November 2014), 018. Retrieved from https://www.rese archgate.net/publication/301895562

Cinar, I. Ö., \& Ozturk, A. (2014). The effect of planned baby care education given to primiparous mothers on maternal attachment and selfconfidence levels. Health Care for Women International, 35(3), 320333. https://doi.org/10.1080/0739933 2.2013.842240

Dagvadorj, A., Nakayama, T., Inoue, E., Sumya, N., \& Mori, R. (2017). Cluster randomised controlled trial showed that maternal and child health handbook was effective for child cognitive development in Mongolia. Acta Paediatrica, International Journal of Paediatrics, 
106(8), 1360-1361. https://doi.org/1 $0.1111 /$ apa.13864

Dalton, J. A., Rodger, D., Wilmore, M., Humphreys, S., Skuse, A., Roberts, C. T., \& Clifton, V. L. (2018). The health-e babies app for antenatal education: Feasibility for socially disadvantaged women. PloS ONE, 13(5), e0194337. https://doi.org/10.1 371/journal.pone.0194337

Danaei, G., Andrews, K. G., Sudfeld, C. R., Fink, G., McCoy, D. C., Peet, E., ... Fawzi, W. W. (2016). Risk factors for childhood stunting in 137 developing countries: A comparative risk assessment analysis at global, regional, and country levels. PLOS Medicine, 13(11), 1-19. https://doi.or g/10.1371/journal.pmed.1002164

Davis, B., \& Summers, M. (2015). Engineering Leaders Conference 2014 Applying Dale's Cone of Experience to increase learning and retention: A study of student learning in a foundational leadership course. Engineering Leaders Conference 2014, 4(2015), 6. https://doi.org/10.5339/qproc.2015.el c2014.6

Fasanghari, M., Kordi, M., \& Asgharipour, N. (2019). Effect of maternal role training program based on Mercer theory on maternal self-confidence of primiparous women with unplanned pregnancy. Journal of Education and Health Promotion, 8(4). https://doi.org/10.4103/jehp.jeh p_202_17

Gibson, L., \& Hanson, V. L. (2013). Digital motherhood: How does technology help new mothers?. In Proceedings of the SIGCHI Conference on Human Factors in Computing Systems (pp. 313-322). https://doi.org/10.1145/2470654.247 0700

Ha, J., \& Kim, Y. (2013). Factors influencing self-confidence in the maternal role among early postpartum mothers. Korean Journal of Women Health Nursing, 19(1), 48-56. https://doi.org/10.4069/kjwhn. 2013.19.1.48

Kementerian Kesehatan RI Badan Penelitian dan Pengembangan. (2018). Hasil Utama Riset Kesehatan Dasar. Kementrian Kesehatan Republik Indonesia, 1100. Retrieved from https://doi.org/1 Desember 2013

Kenanga Purbasary, E., Rustina, Y., \& Budiarti, T. (2017). Increasing confidence and ability in implementing kangaroo mother care method among young mothers. Comprehensive Child and Adolescent Nursing, 40(sup1), 1-7. https://doi.org/10.1080/24694193.20 17.1386964

Kristensen, I. H., Simonsen, M., Trillingsgaard, T., Pontoppidan, M., \& Kronborg, H. (2018). First-time mothers' confidence mood and stress in the first months postpartum: A cohort study. Sexual and Reproductive Healthcare, 17, 43-49. https://doi.org/10.1016/j.srhc.2018.0 6.003

Kucukoglu, S., \& Celebioglu, A. (2014). Effect of natural feeding education on successful exclusive breast feeding and breast feeding self efficacy of low birth weight infants. Iranian Journal of Pediatrics, 24(1), 49-56. Retrieved from https://www.ncbi.nlm.nih.gov/pubme d/25793045

Kuo, C.-P., Chuang, H.-L., Lee, S.-H., Liao, W.-C., Chang, L.-Y., \& Lee, M.C. (2012). Parenting confidence and needs for parents of newborns in Taiwan. Iranian Journal of Pediatrics, 22(2), 177-184. Retrieved from http://www.pubmed central.nih.gov/articlerender.fcgi?arti $\mathrm{d}=3446057 \&$ tool=pmcentrez\&rendert ype $=$ abstract 
Ledford, C. J. W., Canzona, M. R., Cafferty, L. A., \& Hodge, J. A. (2016). Mobile application as a prenatal education and engagement tool: A randomized controlled pilot. Patient Education and Counseling, 99(4), 578-582. https://doi.org/10.10 16/j.pec.2015.11.006

Ledford, C. J. W., Womack, J. J., Rider, H. A., Seehusen, A. B., Conner, S. J., Lauters, R. A., \& Hodge, J. A. (2018). Unexpected effects of a system-distributed mobile application in maternity care: A randomized controlled trial. Health Education and Behavior, 45(3), 323-330. https://doi.org/10.1177/10901981177 32110

Lee, J. Y., \& Kim, H. Y. (2017). Development and validation of a postpartum care mobile application for first-time mothers. Korean Journal of Women Health Nursing, 23(3), 210-220. https://doi.org/10.40 69/kjwhn.2017.23.3.210

Mori, R., Yonemoto, N., Noma, H., Ochirbat, T., Barber, E., Soyolgerel, G., ... Lkhagvasuren, O. (2015). The maternal and child health $(\mathrm{MCH})$ handbook in Mongolia: A clusterrandomized, controlled trial. PloS One, 10(4), 1-12. https://doi.org/10.1 371/journal.pone.0119772

Mousavi, S. S., Chaman, R., Khosravi, A., Mohagheghi, P., Mousavi, S. A., \& Keramat, A. (2016). The needs of parents of preterm infants in Iran and a comparison with those in other countries: A systematic review and meta-analysis. Iranian Journal of Pediatrics, 26(5). https://doi.org/10.5 812/ijp.4396

Osaki, K, Kosen, S., E, I., K, P., \& T, H. (2015). Factors affecting the utilisation of maternal, newborn, and child health services in Indonesia: The role of the Maternal and Child Health Handbook. Public Health, 129(5), 582-586. https://doi.org/10. 1016/j.puhe.2015.01.001
Osaki, Keiko, Hattori, T., Toda, A., Mulati, E., Hermawan, L., Pritasari, K., ... Kosen, S. (2019). Maternal and Child Health Handbook use for maternal and child care: A cluster randomized controlled study in rural Java, Indonesia. Journal of Public Health, 41(1), 170-182. https://doi. org/10.1093/pubmed/fdx175

Prabhakaran, H. (2015). Enhancing maternal knowledge in improving life of low birth weight babies. IOSR Journal of Nursing and Health Science, 4(4), 71-77. https://doi.org/ 10.9790/1959-04477177

Premji, S. S., Pana, G., Currie, G., Dosani, A., Reilly, S., Young, M., ... Lodha, A. K. (2018). Mother's level of confidence in caring for her late preterm infant: A mixed methods study. Journal of Clinical Nursing, 27(5-6), e1120-e1133. https://doi. org/10.1111/jocn. 14190

Prendergast, A. J., \& Humphrey, J. H. (2014). The stunting syndrome in developing countries. Paediatrics and International Child Health, 34(4), 250-265. https://doi.org/https://doi. org/10.1179/2046905514Y.0000000 158

Ribeiro, N. A., \& Kase, J. S. (2017). The evolution of parental selfefficacy in knowledge and skill in the home care of preterm infants. Journal of Pediatric and Neonatal Individualized Medicine, 6(1). https://doi.org/10.7363/060118

Rustina, Y., Wanda, D., Waluyanti, F. T., \& Kusumasari, A. P. (2016). Nurses' and parents' perspectives on low birth weight infants discharge planning at a secondary government hospital in Jakarta, Indonesia: A case study. Neonatal, Paediatric and Child Health Nursing, 19(1), 2-6. Retrieved from https://search.infor mit.com.au/documentSummary; $\mathrm{dn}=2$ 01253166785415;res=IELHEA 
Sharma, C., Dirin, A., \& Hosseini, B. (2017). Mobile learning concept for parenting. International Conference of Education Research and Inovation, 2559-2567. https://doi.org/ 10.21125/iceri.2017.0723

Sjarif, D. R., Yuliarti, K., Lestari, E. D., Sidiartha, I. G. L., Nasar, S. S., \& Mexitalia, M. (2015). Rekomendasi praktik pemberian makan berbasis bukti pada bayi dan balita di Indonesia untuk mencegah malnutrisi. Jakarta: Ikatan Dokter Anak Indonesia.

Stewart, C. P., lannotti, L., Dewey, K. G., Michaelsen, K. F., \& Onyango, A. W. (2013). Contextualising complemen tary feeding in a broader framework for stunting prevention. Maternal and Child Nutrition, 9(S2), 27-45. https://doi.org/10.1111/mcn.12088

Susilowati, D. (2016). Promosi kesehatan. Jakarta: PPSDM Kementrian Kesehatan RI.

UNESCO. (2013). Policy guidelines for mobile learning. United Nations Educational, Scientific and Cultural Organization. Retrieved from https://unesdoc.unesco.org/ark:/482 23/pf0000219641
Usman, H. R., Akhtar, S., Habib, F., \& Jehan, I. (2009). Redesigned immunization card and center-based education to reduce childhood immunization dropouts in urban Pakistan: A randomized controlled trial. Vaccine, 27(3), 467-472. https://doi.org/10.1016/j.vaccine.200 8.10.048

Usman, H. R., Rahbar, M. H., Kristensen, S., Vermund, S. H., Kirby, R. S., Habib, F., \& Chamot, E. (2011). Randomized controlled trial to improve childhood immunization adherence in rural Pakistan: Redesigned immunization card and maternal education. Tropical Medicine and International Health, 16(3), 334-342. https://doi.org/10.11 11/j.1365-3156.2010.02698.x

Yanagisawa, S., Soyano, A., Igarashi, H., Ura, M., \& Nakamura, Y. (2015). Effect of a maternal and child health handbook on maternal knowledge and behaviour: A community-based controlled trial in rural Cambodia. Health Policy and Planning, 30(9), 1184-1192. https://doi.org/10.1093/h eapol/czu133 